\title{
Krzysztof Jarosiński
}

\section{REGIONALNE INWESTYCJE PUBLICZNE W POLSCE W LATACH 2008-2013}

\section{Wprowadzenie}

Czas transformacji ustrojowej oraz społeczno-gospodarczej wykazał, że sektor publiczny stał się ważną dziedziną również w warunkach gospodarki rynkowej. Rola jednostek organizacyjnych sektora publicznego zdecydowanie wzrosła i wiązała się z wyraźnym zwiększeniem ich wpływu na szeroko postrzegane procesy rozwojowe. W zmieniających się warunkach gospodarowania sektor publiczny stał się ważnym czynnikiem wsparcia rozwoju społeczno-gospodarczego. W okresie tym stało się oczywiste, że procesy rozwojowe będą wiązały się z koniecznością poniesienia znaczących nakładów inwestycyjnych zarówno w sektorze przedsiębiorstw prywatnych, jak i w sferze zróżnicowanych zakresów działalności podmiotów zaliczanych do sektora publicznego.

Głównym zadaniem polityki inwestycyjnej w okresie transformacji oraz po przystąpieniu Polski do Unii Europejskiej była konieczność zwiększenia nakładów inwestycyjnych w sektorze prywatnym i w sektorze publicznym. Polityka inwestycyjna w owym czasie musiała być prowadzona $\mathrm{z}$ uwzględnieniem daleko idącej autonomii jednostek samorządu terytorialnego różnych szczebli, a także z uwzględnieniem znacznego rozproszenie zadań i kompetencji, zwłaszcza w odniesieniu do jednostek samorządu terytorialnego na poziomie lokalnym. Należy pamiętać, że jednostki samorządu terytorialnego nabyły uprawnienia do samodzielnego prowadzenia polityki rozwoju i choć ogólne ramy działania oraz zakres kompetencji zostały określone $\mathrm{w}$ regulacjach ustawowych, to jednak zakres autonomii dawał prawo swobodnego wyboru własnej ścieżki rozwoju i tym samym własnej polityki inwestycyjnej.

Wobec celów polityki regionalnej Unii Europejskiej polityka inwestycyjna oraz sam proces inwestycyjny jednostek samorządu terytorialnego zostały powiązane z celami społeczności na poziomie lokalnym, a także celami ujmowanymi nieco szerzej na poziomie regionalnym. 
W ramach przeprowadzonego badania została podjęta analiza i ocena gospodarczych efektów polityki inwestycyjnej regionów, co w istocie odpowiadało badaniu sytuacji jednostek samorządu terytorialnego na poziomie województw samorządowych. Głównym przedmiotem zainteresowania stały się wydatki inwestycyjne i majątkowe w latach 2008-2013. Przyjęty horyzont czasowy badania ma charakter wycinkowy, został on podyktowany kilkoma przesłankami. Pierwszą z nich była chęć przedstawienia zachodzących przemian w gospodarce regionalnej wobec uczestnictwa Polski w polityce spójności kolejnego okresu programowania budżetowego Unii Europejskiej zaplanowanego na lata 2007-2013 i związanymi z tym okresem znacznymi planowanymi transferami środków finansowych $z$ budżetu Unii. Drugą była chęć przedstawienia zachodzących przemian społeczno-gospodarczych już po kilku latach członkowstwa, kiedy Polska posiadała już dodatkowe możliwości finansowego wsparcia procesów rozwojowych ze strony budżetu UE w ramach pełnego 7-letniego okresu programowania budżetowego Unii. Kolejną przesłanką była chęć ujawnienia przemian, jakie zaszły i następowały w warunkach szerszego rozwinięcia procesów inwestycyjnych $\mathrm{w}$ regionach. Jednym $\mathrm{z}$ powodów ograniczenia zakresu opracowania były także przesłanki o charakterze formalnym, nakładające pewne ograniczenia objętościowe odnośnie do przygotowywanego tekstu.

W artykule podjąłem zatem próbę analizy i oceny gospodarki finansowej i inwestycji na poziomie regionów w kontekście prowadzonej polityki inwestycyjnej regionów w Polsce w latach 2008-2013. Czas objęty badaniem jest stosunkowo krótki i wynika z potrzeby objęcia analizą okresu programowania budżetowego 2007-2013 Unii Europejskiej, w ramach którego w Polsce wykorzystywano środki na inwestycje pochodzące ze zróżnicowanych źródeł. Takie ujęcie wydaje się być uzasadnione $\mathrm{z}$ uwagi na znaczące zmiany ilościowe oraz jakościowe, a także z uwagi na kształt polityki inwestycyjnej prowadzonej w tym czasie przez jednostki samorządu terytorialnego na poziomie regionalnym.

\section{Inwestycje na poziomie regionów w Polsce w latach 2008-2013 wobec nowej polityki inwestycyjnej w warunkach członkostwa w UE}

Wraz z przystąpieniem do Unii Europejskiej Polska znalazła się w całkowicie nowej sytuacji, jeśli chodzi o relacje $\mathrm{z}$ otoczeniem zewnętrznym, $\mathrm{w}$ tym zwłaszcza z krajami członkowskimi Unii. Okres programowania, do którego również włączono Polskę, miał charakter przejściowy i wiązał się z koniecznością stosunkowo szybkiej 
absorpcji środków budżetowych wynikających z podziału pomiędzy państwa członkowskie, $\mathrm{w}$ tym także pomiędzy państwa przystępujące w ramach kolejnego rozszerzenia w roku 2004.

Lata 2004-2006 cechowały się scentralizowaniem decyzji na poziomie krajowym co do alokacji środków unijnych w odniesieniu do planowanych przedsięwzięć inwestycyjnych. W owym czasie mieliśmy do czynienia $\mathrm{z}$ sytuacją wdrożenia na poziomie administracji centralnej procedur związanych $z$ udzielaniem wsparcia unijnego. Było jednak oczywiste, że jest to stan przejściowy, który będzie ewoluował w kierunku nadania regionom pełnej podmiotowości prowadzenia własnej polityki regionalnej i co za tym idzie również polityki inwestycyjnej.

Daleko idące zmiany zaszły już w okresie programowania 2007-2013. Nastąpiła zatem znaczna decentralizacja zadań i kompetencji na rzecz regionów z równoczesnym ograniczeniem wpływu administracji centralnej na kształt polityki regionalnej $\mathrm{w}$ regionach. Znaczące miejsce w kształtowaniu polityki regionalnej zajęły opracowywane regionalne programy operacyjne, które następnie stawały się przedmiotem oceny i negocjacji pomiędzy dysponentem środków, w warunkach polskich - Ministerstwa Rozwoju Regionalnego a władzami regionalnymi.

Należy podkreślić, że polityka regionalna poszczególnych regionów w państwach członkowskich Unii nie mogła być realizowana z zachowaniem całkowitej autonomii podejmowanych decyzji. Z oczywistych powodów, w tym przede wszystkim z uwagi na nadrzędne cele Unii Europejskiej, kierunki polityki regionalnej musiały być skorelowane z ramowymi wytycznymi wynikającymi właśnie z priorytetów polityki regionalnej całej Unii Europejskiej jako instytucji.

Zwiększenie znaczenia polityki inwestycyjnej jednostek samorządu terytorialnego w Polsce nastąpiło z chwilą uzyskania uprawnień decyzyjnych przez społeczności lokalne na poziomie gminnym oraz w późniejszym okresie na poziomie regionalnym, kiedy wiadomo już było, że Polska będzie ubiegać się o przystąpienie do struktur Unii Europejskiej. Przełomowym momentem było dostrzeżenie rangi koniecznych zmian o charakterze systemowym i transformacyjnym w gospodarce i co się z tym wiązało - daleko idących zmian na rzecz tworzenia podstaw demokracji lokalnej. W tym znaczeniu za przełomowy należy uznać rok 1989 oraz następujące po nim dynamiczne zmiany w strukturze władz publicznych i w strukturze gospodarki. Poszukując odpowiedzi na pytanie odnośnie do genezy, skali oraz skuteczności realizacji polityki inwestycyjnej na poziomie lokalnym i regionalnym, należy z całą pewnością odwołać się do uchwalonej 8 marca 1990 r. ustawy o samorządzie terytorialnym. Zapoczątkowany wówczas proces zmian zapewnił daleko idącą autonomię w wyborze kierunków rozwoju. Rozwiązanie to stanowiło niewątpliwie całkowicie nowy element w strukturze państwa, dawało ono bowiem mieszkańcom wspólnoty 
samorządowej realne prawo współdecydowania w sprawach dla nich najistotniejszych. Wspomniana ustawa likwidowała $\mathrm{w}$ istocie monopol państwa w sferze polityki publicznej na poziomie lokalnym, w tym również w sferze polityki inwestycyjnej.

Nowe inwestycje podejmowane $\mathrm{w}$ ramach polityki inwestycyjnej państwa oraz samorządu terytorialnego, a także własnej polityki inwestycyjnej przedsiębiorstw stały się głównym czynnikiem sprawczym postępu, demokratycznych przemian oraz poprawy sytuacji materialnej mieszkańców, dostrzegających już w początkowym okresie transformacji dobry klimat dla rozwoju przedsiębiorczości w Polsce.

$\mathrm{W}$ owym czasie mieliśmy do czynienia $\mathrm{z}$ wyzwoleniem szerokiego strumienia nowych inwestycji o charakterze rozwojowym oraz modernizacyjnym w przedsiębiorstwach oraz z szerokim strumieniem nowych inwestycji w obszarze zadań własnych podmiotów sektora publicznego, w szczególności jednostek samorządu terytorialnego oraz państwa. Należy jednak podkreślić, że charakter inwestycji realizowanych w szeroko rozumianym sektorze publicznym miał swoją specyfikę, wynikającą z licznych uwarunkowań tego sektora gospodarki. Z uwagi na publiczny charakter zasobów oraz stawianych celów rozwojowych inwestycje podejmowane w sektorze publicznym wiązały się wówczas, a także współcześnie z koniecznością oceny oraz przeprowadzenia dyskusji publicznej na temat zasadności planowanych działań, ich kosztów bieżących oraz przyszłych, a także korzyści ujmowanych szerzej w formie korzyści społecznych.

W polityce inwestycyjnej jednostek samorządu terytorialnego można wyodrębnić pięć ważnych okresów:

- okres gospodarki centralnie administrowanej do roku 1989, charakteryzujący się niskim wolumenem nakładów w sferze gospodarki komunalnej oraz niską efektywnością, a także zacofaniem technicznym i technologicznym;

- lata 1990-1998, cechujące się intensyfikacją procesów transformacyjnych oraz szybkim rozwojem zróżnicowanych demokracji lokalnej; w rezultacie nastąpiło znaczne ugruntowanie pozycji jednostek samorządu terytorialnego oraz ostatecznie przejęcie w sposób trwały własnych zadań i pełne wykorzystanie nabytych kompetencji przez społeczności lokalne; w okresie tym rozpoczęto także prace koncepcyjne i legislacyjne o charakterze przedakcesyjnym, zgodnie z koncepcją przystąpienia Polski do Unii Europejskiej, wynikającą z przyjęcia przez Polskę w 1994 r. w Essen strategii przedakcesyjnej;

- okres 1999-2004, bezpośrednio poprzedzający przystąpienie Polski do UE, związany $\mathrm{z}$ wielotorowymi działaniami ze strony państwa, prowadzącymi do wypełnienia kryteriów integracji ujętych w poszczególnych rozdziałach problemowych;

- lata 2004-2006, czas włączenia się Polski w mechanizmy programowania budżetowego UE na lata 2000-2006; 
- lata 2007-2013, okres pełnoprawnego uczestnictwa Polski w programie wsparcia w ramach polityki spójności UE ${ }^{1}$.

Ujawnione zjawiska doprowadziły do nowej jakościowo sytuacji, w której aktywność na poziomie lokalnym powiązana została z potrzebą osiągania celów nieco bardziej odległych; również możliwości finansowego wsparcia procesów rozwojowych doprowadziły do nowej jakościowo sytuacji polegającej na szerszym otwarciu się władz publicznych oraz społeczności lokalnych na zróżnicowane formy współpracy $z$ otoczeniem zewnętrznym ${ }^{2}$.

Zachodzące w tym czasie przeobrażenia wydatnie przyczyniły się do wyraźnej zmiany pozycji jednostek samorządu terytorialnego. Pierwotnie zakreślona koncepcja gospodarki budżetowej, choć co do zasady pozostaje bez zmian, uległa jednak weryfikacji na rzecz wprowadzenia i uruchomienia nowych instrumentów finansowych oraz zastosowania nowych rozwiązań. W rezultacie jednostki samorządu terytorialnego podjęły aktywną politykę rozwoju, w tym właśnie politykę inwestycyjną polegającą na zwiększaniu otwartości w stosunku do podmiotów publicznych, a także w stosunku do podmiotów wywodzących się z sektora prywatnego.

Jednostki samorządu terytorialnego różnych szczebli znacząco wzmocniły politykę inwestycyjną, posiłkując się często środkami o charakterze pozabudżetowym. W znacznej mierze były to początkowo środki zwrotne, kierowane na urzeczywistnienie celów zakreślonej polityki inwestycyjnej, posiadające formę kredytów bankowych lub pożyczek. Polityka inwestycyjna oparta na takich zewnętrznych źródłach finansowania stworzyła możliwości zwiększenia stopy inwestycji oraz prowadziła do zwiększenia efektów rzeczowych inwestycji. W dłuższym okresie taka polityka inwestycyjna nie mogła być jednak utrzymana $z$ uwagi na wzrost deficytu budżetowego i często w konsekwencji prowadziła do nadmiernego zadłużenia. Negatywne zjawiska współfinansowania zadań w ramach takiej polityki inwestycyjnej nie występowały powszechnie. Obserwowano jednostki osadnicze borykające się z problemami obsługi zadłużenia, z drugiej strony mieliśmy do czynienia z jednostkami, w których sytuacja w zakresie gospodarki finansowej miała charakter zrównoważony.

W przedłożonym badaniu zasadnicza uwaga skierowana jest na lata 2008-2013, kiedy to nastąpiło istotne zmodyfikowanie warunków finansowania inwestycji. Możliwość wykorzystania środków o charakterze bezzwrotnym w znaczącym stopniu

1 K. Jarosiński, Uwarunkowania i kierunki polityki inwestycyjnej samorzadu terytorialnego na poziomie regionalnym $w$ Polsce $w$ latach 2004-2013, oprac. przygotowane w ramach badań statutowych „Wybrane regionalne polityki publiczne w warunkach rozwoju zrównoważonego w Polsce w roku 2014", SGH, Warszawa 2014, s. 95-96.

2 K.J. Arrow, M. Kurz, Public Investment, the Rate of Return, and Optimal Fiscal Policy, J.H. University, New York 2011, s. 15. 
poprawiła wskaźniki ekonomiczno-finansowe jednostek samorządu terytorialnego w porównaniu z sytuacją mającą miejsce w okresach wcześniejszych. Należy przypomnieć, że wtedy polityka inwestycyjna oraz finansowanie inwestycji podporządkowane były ogólnym zasadom gospodarki budżetowej. Co prawda jednostki samorządu terytorialnego wykorzystywały na realizację przedsięwzięć inwestycyjnych środki o charakterze pozabudżetowym, które stanowiły dotacje celowe, oraz kredyty czy pożyczki, jeśli jednak chodzi o dotacje, miały one zawsze ograniczony charakter i podlegały stopniowo substytucji na rzecz innych instrumentów finansowych. Co do kredytów i pożyczek oraz innych instrumentów o charakterze zwrotnym, jak choćby emisje obligacji komunalnych, to stanowiły one zasadniczo jedynie dodatkowe źródło finansowania zadań w stosunku do źródeł budżetowych ${ }^{3}$.

\section{Analiza i ocena polityki inwestycyjnej oraz inwestycji regionalnych w latach 2008-2013}

Wsparcie w ramach funduszy strukturalnych udzielone Polsce, a także uruchomienie innych form finansowania inwestycji spowodowały, że na poziomie regionów nastąpiły znaczące zmiany w podejściu do realizacji własnej polityki inwestycyjnej. Zmiany te polegały na możliwości zwiększenia wolumenu nakładów inwestycyjnych, i co za tym idzie - zwiększenia zakresu rzeczowego nowych inwestycji, z drugiej jednak strony wpływ unijnej polityki spójności modyfikował wyznaczone lokalnie priorytety rozwojowe.

Odnośnie do kierunków inwestycji w ramach nowej polityki inwestycyjnej, na pierwszym miejscu znalazł się rozwój infrastruktury społecznej i technicznej. Trzeba bowiem pamiętać, że z chwilą przystąpienia Polski do Unii Europejskiej poza licznymi innymi dysproporcjami rozwojowymi w sferze infrastruktury dysproporcje były szczególnie wyraźnie widoczne i stanowiły poważne ograniczenie dalszego rozwoju społeczno-gospodarczego kraju.

Do najważniejszych zadań samorządu terytorialnego na poziomie województwa (regionu) należą, zgodnie z art. 14 ustawy z dnia 5 czerwca 1998 r. o samorządzie województwa, zadania o charakterze wojewódzkim określone dodatkowo innymi ustawami, w szczególności w zakresie: edukacji publicznej, w tym szkolnictwa wyższego, promocji i ochrony zdrowia, kultury oraz ochrony zabytków i opieki nad zabytkami, pomocy społecznej, wspierania rodziny i systemu pieczy zastępczej,

\footnotetext{
3 K. Jarosiński, op.cit., s. 96-97.
} 
polityki prorodzinnej, modernizacji terenów wiejskich, zagospodarowania przestrzennego, ochrony środowiska, gospodarki wodnej, w tym ochrony przeciwpowodziowej, a w szczególności wyposażenia i utrzymania wojewódzkich magazynów przeciwpowodziowych, transportu zbiorowego i dróg publicznych, kultury fizycznej i turystyki, ochrony praw konsumentów, obronności, bezpieczeństwa publicznego, przeciwdziałania bezrobociu i aktywizacji lokalnego rynku pracy, działalności w zakresie telekomunikacji, ochrony roszczeń pracowniczych w razie niewypłacalności pracodawcy ${ }^{4}$.

Zgodnie z powyższą systematyką to właśnie regiony są odpowiedzialne za realizację kapitałochłonnych zadań z zakresu infrastruktury technicznej oraz społecznej. Ważną częścią gospodarki budżetowej regionów jest zarówno bieżące utrzymanie majątku trwałego przynależnego kompetencyjnie samorządowi województwa, jak i realizacja wielu inwestycji o charakterze odtworzeniowym, modernizacyjnym oraz rozwojowym. $Z$ uwagi na charakter obiektów infrastruktury inwestycje samorządu terytorialnego na poziomie regionalnym muszą być podporządkowane jasno zakreślonej strategii rozwoju o charakterze długookresowym. Jednym $\mathrm{z}$ ważniejszych zapisów tego rodzaju dokumentów planistycznych powinno być właściwe umiejscowienie polityki inwestycyjnej, która łączyłaby w sobie zagregowany i usystematyzowany zbiór potrzeb oraz realne możliwości finansowania przedsięwzięć inwestycyjnych. Należy pamiętać, że polityka inwestycyjna samorządu terytorialnego w powiązaniu z planowaniem strategicznym stanowią główną oś programowania rozwoju społeczno-gospodarczego na poziomie regionu. Samorząd regionalny zobowiązany jest do wypełniania zróżnicowanych funkcji w stosunku do mieszkańców regionu zorganizowanych w mniejszych jednostkach samorządu terytorialnego na poziomie podstawowym, a także zobowiązany jest pełnić funkcję koordynatora polityki regionalnej, kształtowanej na poziomie państwa w powiązaniu z wytycznymi w tym zakresie wynikającymi z ustaleń podejmowanych na poziomie Unii Europejskiej.

Wzrost znaczenia regionów można zauważyć przez pryzmat wydatków budżetowych. Na potrzeby badania zgromadzono dane liczbowe ilustrujące zmiany w poziomie wydatków budżetowych w latach 2008-2013, które zamieszczono w tabeli 1. Zgodnie z przyjętą formułą analizy uzasadnione jest przedstawienie zmian w poziomie wydatków budżetowych samorządów województw w okresie 2008-2013, co odpowiada formalnie okresowi programowania budżetowego Unii Europejskiej na lata 2007-2013 i partycypacji Polski we wsparciu w ramach funduszy unijnych w wymienionej perspektywie. Dane liczbowe przedstawiono począwszy od roku 2008 z uwagi na występujące opóźnienia w przekazywaniu środków w ramach omawianej perspektywy. 
Tabela 1. Wydatki budżetowe województw ogółem w latach 2008-2013 (w mln zł)

\begin{tabular}{|l|r|r|r|r|r|r|}
\hline \multicolumn{1}{|c|}{ Wyszczególnienie } & \multicolumn{1}{c|}{2008} & 2009 & 2010 & 2011 & 2012 & 2013 \\
\hline Dolnośląskie & 1006,2 & 1590,3 & 1303,4 & 1516,9 & 1687,2 & 1588,3 \\
\hline Kujawsko-pomorskie & 640,7 & 974,5 & 850,8 & 775,0 & 766,1 & 742,3 \\
\hline Lubelskie & 698,6 & 954,3 & 767,2 & 896,8 & 840,8 & 1039,8 \\
\hline Lubuskie & 340,1 & 777,4 & 513,4 & 502,2 & 446,8 & 578,3 \\
\hline tódzkie & 664,3 & 1425,3 & 863,2 & 956,7 & 902,9 & 753,3 \\
\hline Małopolskie & 923,3 & 1498,5 & 1198,8 & 1404,5 & 1142,9 & 1107,3 \\
\hline Mazowieckie & 3079,2 & 3244,3 & 2508,6 & 2595,4 & 2462,9 & 2191,6 \\
\hline Opolskie & 371,9 & 692,2 & 555,0 & 484,3 & 412,1 & 443,2 \\
\hline Podkarpackie & 646,0 & 1150,1 & 979,7 & 962,5 & 891,0 & 1112,2 \\
\hline Podlaskie & 334,5 & 616,4 & 411,7 & 518,2 & 492,2 & 561,0 \\
\hline Pomorskie & 712,2 & 1276,7 & 872,0 & 954,1 & 919,8 & 830,6 \\
\hline Śląskie & 1263,2 & 1729,4 & 1410,0 & 1456,3 & 1469,3 & 1705,5 \\
\hline Świętokrzyskie & 374,1 & 754,3 & 560,9 & 529,6 & 688,3 & 734,3 \\
\hline Warmińsko-mazurskie & 449,5 & 811,1 & 541,4 & 580,5 & 679,5 & 923,9 \\
\hline Wielkopolskie & 962,7 & 1882,5 & 1122,9 & 1353,1 & 1136,1 & 1385,7 \\
\hline Zachodniopomorskie & 536,0 & 1091,4 & 786,1 & 852,5 & 822,7 & 829,6 \\
\hline
\end{tabular}

Źródło: Opracowanie własne na podstawie danych GUS.

Wzrost znaczenia regionów w Polsce był obserwowany niemal od początku reformy administracji publicznej, a więc od $1999 \mathrm{r}$. Z uwagi jednak na nieco inną pozycję ówczesnych regionów, a zwłaszcza słabą sytuację dochodową, regiony - choć ustawowo zobligowane zostały do realizacji określonego pakietu zadan - nie mogły podejmować szerszych działań, zwłaszcza o charakterze inwestycyjnym, właśnie $\mathrm{z}$ uwagi na sytuację finansową. Znacząca zmiana $\mathrm{w}$ tym zakresie nastąpiła $\mathrm{z}$ chwilą przystąpienia Polski do Unii Europejskiej, kiedy wolumen wydatków budżetowych regionów znacząco wzrastał. W interesującym nas okresie 2008-2013 sytuacja budżetowa regionów ulegała różnokierunkowym zmianom. O ile w latach 2008-2009 miał miejsce sukcesywny wzrost dochodów, zgodny zresztą z tendencją obserwowaną w latach wcześniejszych, to jednak od roku 2010 odnotowano znaczące obniżenie wolumenu wydatków. Zmiany w tym zakresie zostały przedstawione w tabeli 1 oraz zilustrowane graficznie na rysunku 1.

Choć w latach wcześniejszych 2004-2007 odnotowano wysokie wskaźniki wzrostu wydatków budżetowych we wszystkich regionach, to już w latach w 2008-2013 stagnację, a nawet spadki wydatków. Zasadniczo odmienna sytuacja wystąpiła w regionie mazowieckim, gdzie w latach 2009-2013 wydatki budżetowe zmniejszyły się o kwotę 1971,9 mln zł, co oznaczało obniżenie tych wydatków w 2013 r. 
w porównaniu z 2008 r. o $64,0 \%{ }^{4}$. W pozostałych regionach w Polsce w tym samym czasie wolumen wydatków budżetowych regionów ulegał wahaniom, nie wykazując przy tym charakteru wzrostowego. Rok 2009 był ostatnim z dłuższego okresu wzrostów wydatków budżetowych. Szczególnie korzystna sytuacja w tym zakresie utrzymywała się w latach wcześniejszych 2004-2007, kiedy odnotowano systematyczny wzrost wydatków budżetowych w regionach. W latach 2008-2013 odnotowano dalszy wzrost wydatków budżetowych w regionach. Szczególnie wysokie wydatki oraz wzrost dynamiki odnotowano do roku $2009 \mathrm{w}$ regionie mazowieckim, jednakże w kolejnych latach poziom wydatków budżetowych w tym regionie ulegał stopniowemu obniżaniu, osiągając w 2013 r. poziom niższy od poziomu wyjściowego w 2007 r.

Rysunek 1. Wielkość wydatków budżetowych regionów w Polsce w latach 2008-2013 ( $w$ mln zl)

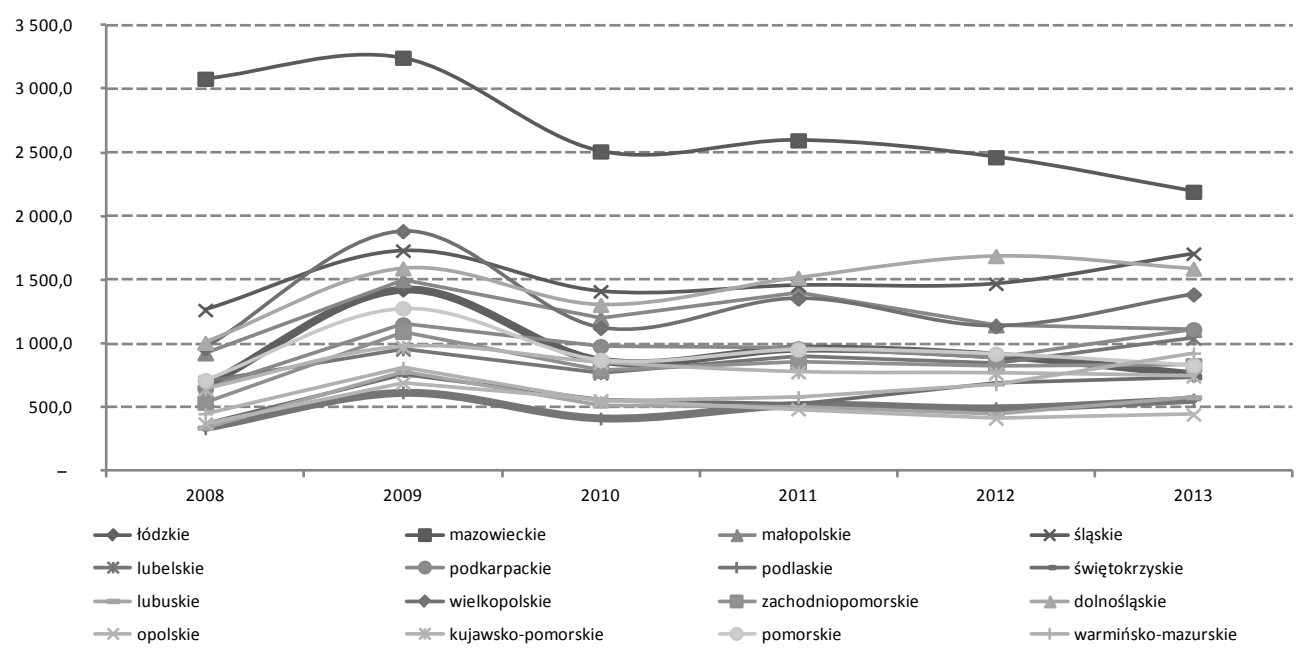

Źródło: Opracowanie własne.

Zmiany po stronie wydatków budżetowych w regionach w Polsce po roku 2008 miały szereg przyczyn, m.in. światowy kryzys finansowy obserwowany również w Polsce, a także obniżenie bazy finansowej, stanowiącej podstawę zasilania finansowego budżetów, spadek dochodów przedsiębiorstw jako rezultat ograniczenia efektywnego popytu i produkcji. W efekcie oddziaływania tych niekorzystnych czynników nastąpiło obniżenie tempa wzrostu PKB oraz obniżenie wolumenu środków unijnych, kierowanych po roku 2010 na finansowanie zadań w okresie programowania 2007-2013. Jak wspomniałem, najwyższy poziom wydatków budżetowych

4 Na podstawie obliczeń własnych. 
odnotowano we wszystkich niemal regionach w 2009 r., wyjątkiem była sytuacja zaistniała $\mathrm{w}$ regionie dolnośląskim, gdzie poziom wydatków z roku 2009 był nieznacznie przekroczony w 2012 r. Jedną z przyczyn obniżenia poziomu wydatków budżetowych regionów były także opóźnienia w alokacji środków oraz opóźnienia $\mathrm{w}$ trakcie realizacji projektów i ich rozliczania.

W tym miejscu warto zwrócić uwagę na wydatki majątkowe budżetów regionów $\mathrm{w}$ Polsce w latach 2008-2103. Zgodnie z przyjętą terminologią wydatki majątkowe obejmują głównie wydatki inwestycyjne oraz wydatki związane z kapitałową partycypacją jednostki w przedsięwzięciach realizowanych przez inne podmioty. Przyjęto, że wydatki majątkowe w większości obejmują wydatki na inwestycje o charakterze rzeczowym oraz wydatki o charakterze finansowym. Szczegółowe dane zostały przedstawione $\mathrm{w}$ tabeli 2 .

Tabela 2. Wydatki majątkowe budżetów województw ogółem w latach 2008-2013 (w mln $\mathrm{zl}$ )

\begin{tabular}{|l|c|c|c|c|c|c|}
\hline \multicolumn{1}{|c|}{ Wyszczególnienie } & 2008 & 2009 & 2010 & 2011 & 2012 & 2013 \\
\hline Dolnośląskie & 316,7 & 781,3 & 478,1 & 636,3 & 801,5 & 617,9 \\
\hline Kujawsko-pomorskie & 208,2 & 444,9 & 321,1 & 245,6 & 224,4 & 167,8 \\
\hline Lubelskie & 304,4 & 359,8 & 271,2 & 376,5 & 308,5 & 503,3 \\
\hline Lubuskie & 111,1 & 480,9 & 229,1 & 184,4 & 139,6 & 181,7 \\
\hline Łódzkie & 232,6 & 832,2 & 362,6 & 412,9 & 362,9 & 248,6 \\
\hline Małopolskie & 420,5 & 817,5 & 578,0 & 731,9 & 462,6 & 431,3 \\
\hline Mazowieckie & 1166,0 & 936,9 & 472,5 & 642,7 & 534,7 & 460,1 \\
\hline Opolskie & 135,2 & 375,1 & 258,7 & 199,6 & 136,1 & 137,8 \\
\hline Podkarpackie & 209,7 & 503,5 & 437,5 & 414,9 & 361,8 & 553,0 \\
\hline Podlaskie & 103,9 & 339,0 & 154,5 & 237,1 & 200,8 & 273,4 \\
\hline Pomorskie & 289,4 & 716,3 & 382,8 & 426,5 & 371,2 & 266,9 \\
\hline Śląskie & 524,1 & 809,3 & 669,0 & 601,6 & 540,5 & 780,3 \\
\hline Świętokrzyskie & 128,4 & 390,1 & 250,0 & 231,5 & 403,7 & 428,0 \\
\hline Warmińsko-mazurskie & 125,6 & 349,4 & 186,3 & 210,2 & 305,7 & 530,8 \\
\hline Wielkopolskie & 312,9 & 1197,2 & 500,4 & 630,1 & 409,4 & 640,7 \\
\hline Zachodniopomorskie & 185,7 & 625,4 & 390,7 & 430,4 & 389,1 & 340,8 \\
\hline
\end{tabular}

Źródło: Opracowanie własne na podstawie danych GUS.

W roku 2008 najwyższy poziom wydatków majątkowych odnotowano w regionie mazowieckim (1166,0 $\mathrm{mln}$ zł). W pozostałych regionach poziom wydatków majątkowych w tym samym czasie był znacząco niższy. W drugim pod względem wartości wydatków majątkowych regionie - śląskim omawiane wydatki wyniosły 524,1 mln zł. 
Kolejnym regionem jeśli chodzi o poziom wydatków majątkowych był w tym czasie region dolnośląski - 316,7 mln zł.

Rysunek 2. Wydatki majątkowe budżetów województw ogółem w latach 2008-2013 (w mln zl)

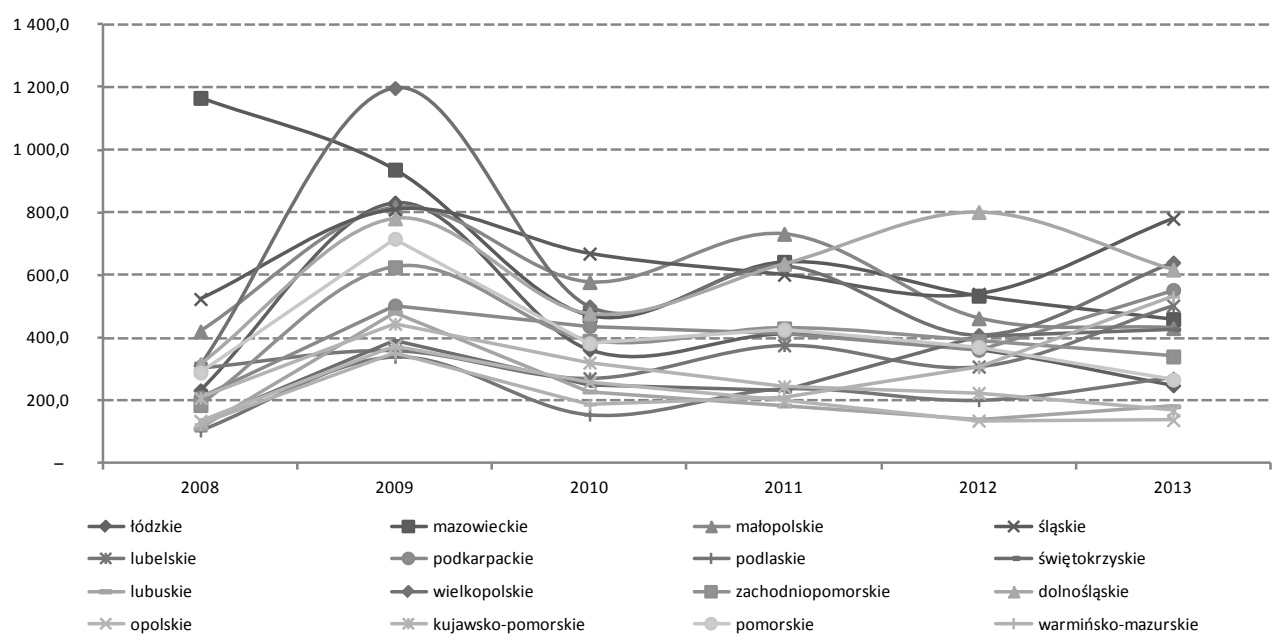

Źródło: Opracowanie własne.

W omawianym okresie 2008-2013 początkowo, w roku 2009, odnotowano dalszy wzrost udziału wydatków majątkowych w wydatkach budżetów regionów ogółem. Sytuacja taka wystąpiła mimo wzrostu wydatków z tytułu obsługi zadłużenia. Należy zwrócić uwagę, że rok 2009 był pierwszym rokiem zwiększenia wolumenu wydatków związanych z obsługą zadłużenia.

Jak wynika z materiału liczbowego oraz ilustracji graficznej, po 2009 r. sytuacja uległa dość znaczącej zmianie. Po pierwsze, odnotowano bezwzględny spadek wydatków budżetowych ogółem we wszystkich województwach w porównaniu z rokiem 2009, bezwzględny spadek wydatków majątkowych i jednocześnie relatywnie wysoki poziom wydatków budżetowych związanych z obsługą zadłużenia. Choć w roku 2013 w porównaniu z rokiem 2009 sytuacja uległa pogorszeniu pod względem wydatków majątkowych, w tym inwestycyjnych, to jednak w roku 2013 $\mathrm{w}$ porównaniu z rokiem 2012 odnotowano nieznaczną poprawę $\mathrm{w}$ tym zakresie. Jak wynika z danych liczbowych oraz ilustracji graficznej, w 2013 r. zaszły nowe zjawiska wskazujące na powolne odwracanie niekorzystnego trendu $z$ lat ubiegłych. Można zatem przyjąć, że zjawiska te są przejawem bardziej trwałej poprawy, co w powiązaniu ze stopniowym obniżaniem się wydatków związanych z obsługą zadłużenia oraz stopniowym wzrostem wydatków majątkowych w ujęciu bezwzględnym może 
być sygnałem nadchodzącej poprawy sytuacji. Z pewnością znaczący wpływ na poprawę sytuacji po roku 2013 będą miały środki kierowane do Polski w ramach wsparcia ze strony Unii Europejskiej przewidziane dla Polski w kolejnym okresie programowania 2014-2020.

Szczególnie ważnym miernikiem oceny procesów inwestycyjnych w regionach jest wskaźnik udziału wydatków majątkowych regionów w wydatkach ogółem. Udział wydatków majątkowych regionów w wydatkach ogółem w latach 2008-2013 przedstawiłem w tabeli 3.

Tabela 3. Udział wydatków majątkowych regionów w wydatkach ogółem w latach 2008-2013 (w \%)

\begin{tabular}{|l|c|c|c|c|c|c|}
\hline \multicolumn{1}{|c|}{ Wyszczególnienie } & 2008 & 2009 & 2010 & 2011 & 2012 & 2013 \\
\hline Dolnośląskie & 31,5 & 49,1 & 36,7 & 41,9 & 47,5 & 38,9 \\
\hline Kujawsko-pomorskie & 32,5 & 45,7 & 37,7 & 31,7 & 29,3 & 22,6 \\
\hline Lubelskie & 43,6 & 37,7 & 35,4 & 42,0 & 36,7 & 48,4 \\
\hline Lubuskie & 32,7 & 61,9 & 44,6 & 36,7 & 31,3 & 31,4 \\
\hline Łódzkie & 35,0 & 58,4 & 42,0 & 43,2 & 40,2 & 33,0 \\
\hline Małopolskie & 45,5 & 54,6 & 48,2 & 52,1 & 40,5 & 38,9 \\
\hline Mazowieckie & 37,9 & 28,9 & 18,8 & 24,8 & 21,7 & 21,0 \\
\hline Opolskie & 36,3 & 54,2 & 46,6 & 41,2 & 33,0 & 31,1 \\
\hline Podkarpackie & 32,5 & 43,8 & 44,7 & 43,1 & 40,6 & 49,7 \\
\hline Podlaskie & 31,1 & 55,0 & 37,5 & 45,8 & 40,8 & 48,7 \\
\hline Pomorskie & 40,6 & 56,1 & 43,9 & 44,7 & 40,4 & 32,1 \\
\hline Śląskie & 41,5 & 46,8 & 47,4 & 41,3 & 36,8 & 45,7 \\
\hline Świętokrzyskie & 34,3 & 51,7 & 44,6 & 43,7 & 58,6 & 58,3 \\
\hline Warmińsko-mazurskie & 27,9 & 43,1 & 34,4 & 36,2 & 45,0 & 57,5 \\
\hline Wielkopolskie & 32,5 & 63,6 & 44,6 & 46,6 & 36,0 & 46,2 \\
\hline Zachodniopomorskie & 34,6 & 57,3 & 49,7 & 50,5 & 47,3 & 41,1 \\
\hline
\end{tabular}

Źródło: Opracowanie własne na podstawie danych GUS.

Należy podkreślić, że udział wydatków majątkowych w poszczególnych regionach w Polsce w latach 2008-2013 kształtował się na stosunkowo wysokim poziomie. $\mathrm{Z}$ pewnością wynika to $\mathrm{z}$ charakteru zadań określonych $\mathrm{w}$ przepisach prawa, trzeba jednak pamiętać, że określone tam zadania wiążą się z koniecznością ponoszenia, obok wydatków o charakterze rozwojowym, również wydatków związanych z bieżącym utrzymaniem i funkcjonowaniem podmiotów świadczących usługi publiczne. Pomiędzy poszczególnymi regionami występowały w tym zakresie dość znaczące różnice. Przykładowo, w roku 2008 omawiany udział w regionie małopolskim kształtował się na poziomie $45,5 \%$, natomiast w regionie warmińsko-mazurskim wynosił 
tylko $27,9 \%$. Na rysunku 3 zostały przedstawione wyniki obliczeń udziału omawianych wydatków w $2008 \mathrm{r}$.

\section{Rysunek 3. Udział wydatków majątkowych regionów w wydatkach ogółem w 2008 r.} $(\mathrm{w} \%)$

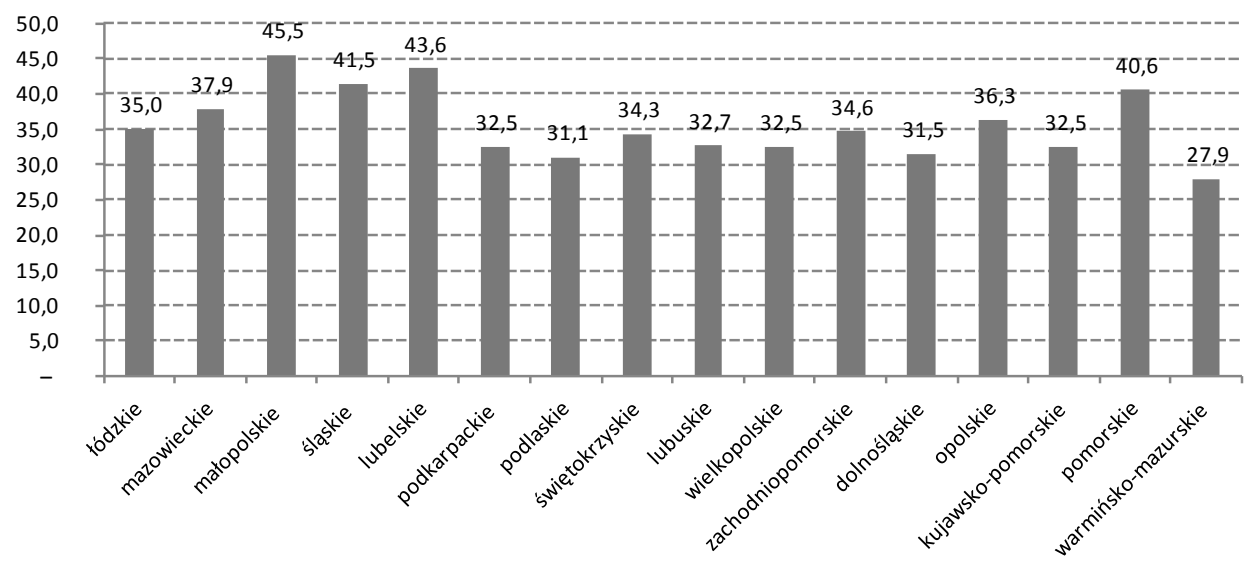

Źródło: Opracowanie własne.

W kolejnych latach omawiany udział wydatków zdecydowanie wzrósł, co było związane z dalszym wzrostem dochodów budżetowych i - co za tym idzie - wydatków budżetowych, w tym na inwestycje. W roku 2013 sytuacja uległa nieznacznemu pogorszeniu, udział wydatków majątkowych, w tym głównie inwestycyjnych, uległ ponownemu obniżeniu i w ośmiu regionach nie osiągnął wartości udziału z roku 2008. Na rysunku 3 zostały przedstawione wyniki obliczeń udziału omawianych wydatków w roku 2013.

W latach 2008-2013 odnotowano zróżnicowane zmiany w zakresie wydatków majątkowych budżetów regionów. Dość specyficzna sytuacja występowała w województwie mazowieckim, gdzie zasadniczo już od roku 2008 obserwowano dość gwałtowny spadek wydatków majątkowych, który - z wyłączeniem 2011 r. - utrzymywał się do końca 2013 r. W roku 2013 udział tej grupy wydatków budżetowych osiągnął relatywnie niski poziom i wynosił $21,0 \%$. Również interesująca sytuacja miała miejsce w regionie wielkopolskim, gdzie w roku 2009 odnotowano bardzo duży przyrost wydatków majątkowych w porównaniu z rokiem 2008. Dość charakterystycznym zjawiskiem w omawianym okresie była stabilizacja wydatków majątkowych po roku 2009. Należy jednak pamiętać, że region mazowiecki jest dość specyficzną jednostką przestrzenną. Dominuje w nim miasto stołeczne Warszawa oraz miasta i miejscowości tworzące wraz z Warszawą obszar funkcjonalny, który charakteryzuje 
się szczególnie dobrymi warunkami rozwoju. Pozostałe obszary regionu znacząco odbiegają od średnich wskaźników dla regionu i mają znacznie mniejszy potencjał rozwojowy. W takich warunkach zmiany $\mathrm{w}$ Warszawie rzutują na zmiany sytuacji w całym regionie.

Rysunek 4. Udział wydatków majątkowych regionów w wydatkach ogółem w 2013 r. $(\mathbf{w} \%)$

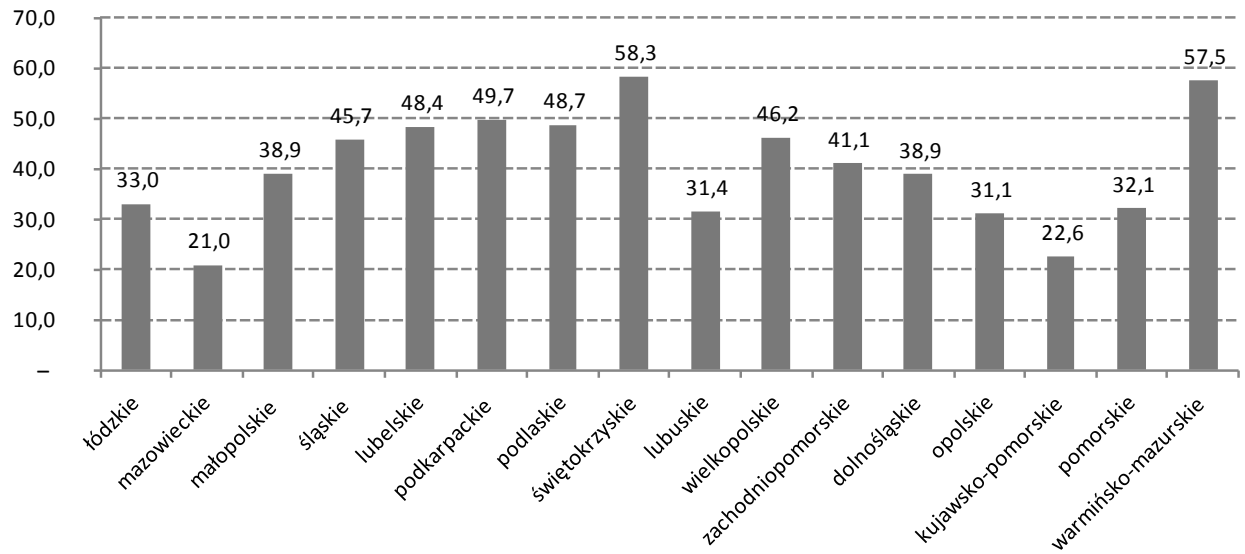

Źródło: Opracowanie własne.

W tym miejscu należy zwrócić uwagę na sytuację związaną z zadłużeniem jednostek samorządu terytorialnego na poziomie regionalnym. Przyspieszone procesy inwestycyjne realizowane $\mathrm{w}$ okresach wcześniejszych pociągnęły za sobą wzrost wydatków związanych z obsługą występującego zadłużenia.

Jednym z powodów zmian sytuacji finansowej regionów był wzrost wydatków związanych z obsługą zadłużenia. W latach 2008-2013 w porównaniu z okresem 2004-2006 obsługa zadłużenia niemal we wszystkich regionach absorbowała znaczące środki. Szczególna sytuacja wystąpiła w regionie mazowieckim, gdzie począwszy od roku 2008 obsługa zadłużenia absorbowała już duże kwoty pieniężne. Nie mogło to pozostać bez wpływu na prowadzenie dalszej polityki inwestycyjnej tego regionu. Jak wynika z zestawień liczbowych oraz ilustracji graficznej, począwszy od 2008 r. wolumen inwestycji w regionie mazowieckim uległ znacznemu ograniczeniu. Oczywiście na sytuację tę złożyło się więcej czynników. Dane liczbowe charakteryzujące wydatki województw związane z obsługą zadłużenia w latach 2008-2013 zostały przedstawione w tabeli 4 .

Obsługa zadłużenia występującego w poszczególnych regionach absorbowała zróżnicowany wolumen środków. Jak już wspomniałem, najwięcej zobowiązań bieżących 
z tytułu zaciągniętych kredytów, wyemitowanych obligacji i pożyczek odnotowano $\mathrm{w}$ regionie mazowieckim. Znacznie niższe wartości obsługi zadłużenia odnotowano w regionach dolnośląskim, śląskim, lubelskim oraz zachodniopomorskim. Nie ulega wątpliwości, że poziom obsługi zadłużenia był w kolejnych latach objętych analizą rezultatem wcześniej podjętych przedsięwzięć inwestycyjnych opracowanych dla poszczególnych projektów ścieżek finansowania z uwzględnieniem zróżnicowanych dostępnych źródeł finansowania. Ilustrację graficzną wydatków związanych z obsługą zadłużenia w latach 2004-2013 przedstawiłem na rysunku 5.

Tabela 4. Wydatki budżetów województw związane z obsługą zadłużenia w latach 2008-2013 (w mln zl)

\begin{tabular}{|l|r|r|r|r|r|r|}
\hline \multicolumn{1}{|c|}{ Wyszczególnienie } & 2008 & 2009 & 2010 & 2011 & 2012 & 2013 \\
\hline Dolnośląskie & 4,9 & 6,5 & 5,9 & 13,0 & 26,6 & 23,2 \\
\hline Kujawsko-pomorskie & 13,1 & 12,4 & 11,5 & 17,6 & 20,1 & 15,5 \\
\hline Lubelskie & 7,4 & 13,1 & 11,7 & 13,4 & 17,0 & 15,1 \\
\hline Lubuskie & 8,0 & 8,5 & 7,7 & 8,8 & 11,5 & 9,1 \\
\hline Łódzkie & 0,2 & 0,1 & 7,8 & 12,3 & 20,2 & 16,8 \\
\hline Małopolskie & 6,2 & 8,9 & 7,9 & 11,9 & 11,2 & 6,5 \\
\hline Mazowieckie & 18,4 & 43,6 & 49,4 & 60,6 & 69,4 & 62,0 \\
\hline Opolskie & 5,5 & 7,8 & 8,6 & 11,8 & 14,5 & 12,8 \\
\hline Podkarpackie & 2,0 & 1,0 & 7,2 & 13,6 & 18,1 & 14,7 \\
\hline Podlaskie & 2,9 & 2,0 & 2,0 & 0,6 & 0,9 & 1,1 \\
\hline Pomorskie & 2,6 & 2,0 & 8,4 & 14,1 & 21,0 & 14,9 \\
\hline Śląskie & 0,1 & 0,0 & 2,2 & 9,8 & 20,2 & 16,2 \\
\hline Świętokrzyskie & 0,2 & 0,0 & - & - & 0,4 & 3,7 \\
\hline Warmińsko-mazurskie & 6,4 & 5,7 & 5,4 & 6,8 & 9,4 & 9,5 \\
\hline Wielkopolskie & 2,6 & 2,2 & 1,1 & 4,4 & 9,3 & 12,1 \\
\hline Zachodniopomorskie & 1,0 & 1,5 & 2,9 & 8,1 & 12,7 & 9,7 \\
\hline
\end{tabular}

Źródło: Opracowanie własne na podstawie danych GUS.

$\mathrm{W}$ tym miejscu warto również przytoczyć dane liczbowe ilustrujące zmiany w poziomie wydatków majątkowych w badanym okresie dla wybranych lat objętych analizą. Na rysunkach 6 i 7 zostały przedstawione wskaźniki tempa zmian wydatków majątkowych w porównaniu $\mathrm{z}$ rokiem poprzednim. $Z$ uwagi na ograniczony zakres analizy nie występuje potrzeba prezentowania dynamiki zmian wydatków majątkowych, w tym inwestycyjnych, dla wszystkich lat okresu objętego analizą, uzasadnione natomiast jest przedstawienie danych przeglądowych w tym zakresie dla wybranych punktów czasowych. 
Rysunek 5. Wydatki budżetów województw związane z obsługą zadłużenia w latach 2008-2013 (w mln zl)

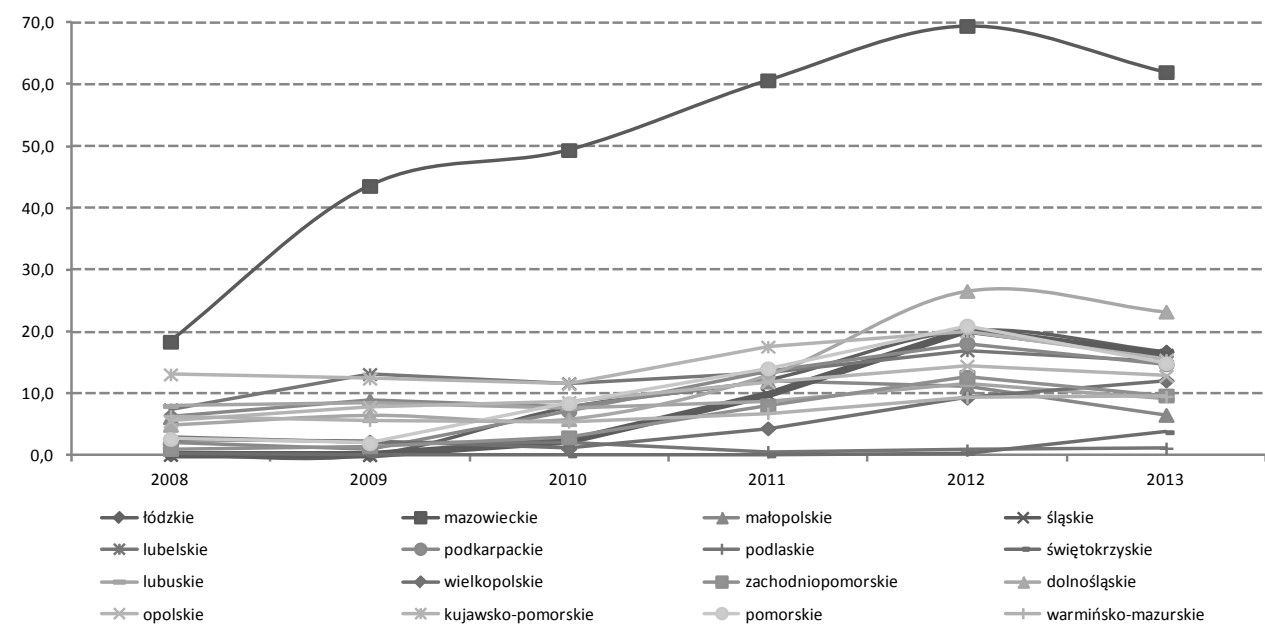

Źródło: Opracowanie własne.

\section{Rysunek 6. Wskaźnik tempa zmian wydatków majątkowych budżetów województw} w 2008 r. (w \%)

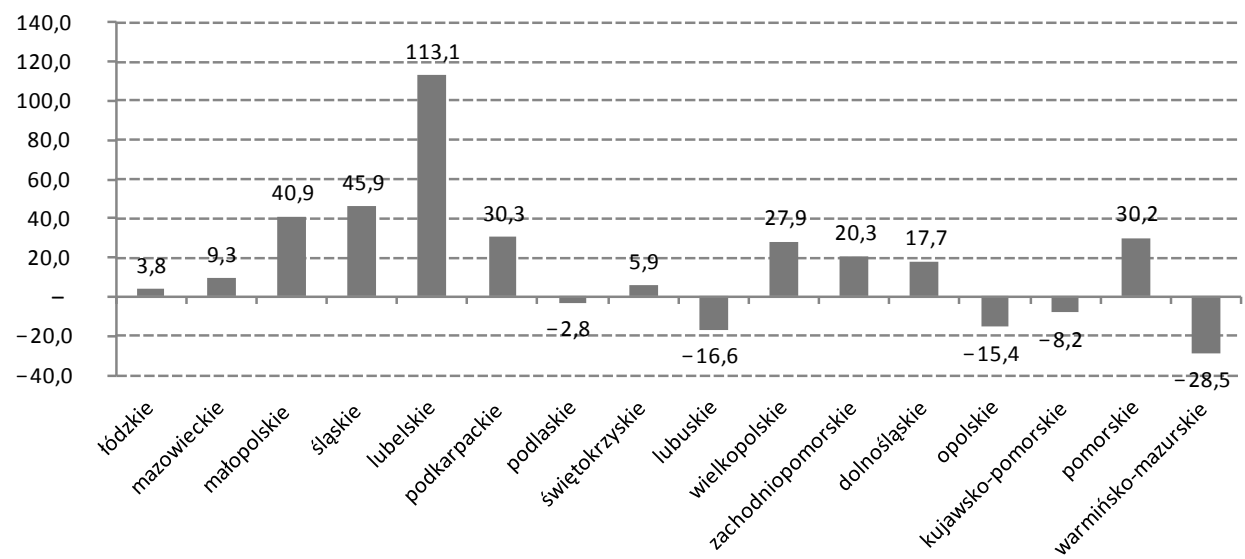

Źródło: Opracowanie własne.

Analiza tempa zmian w poziomie wydatków majątkowych regionalnych jednostek samorządu terytorialnego potwierdza wcześniej rozpoznane prawidłowości kształtowania się polityki inwestycyjnej i powiązanych z nią nakładów inwestycyjnych w regionach. Najlepszym czasem w tym zakresie był rok 2009, kiedy odnotowano znaczny wzrost wydatków. Sytuacji tej nie udało się jednak utrzymać w następnych 
latach i w 2013 r. już w 7 województwach odnotowano spadek wydatków majątkowych w porównaniu z rokiem poprzednim, co skutkowało dość znacznym ujemnym tempem zmian. $Z$ uwagi na wyznaczone cele długookresowe rozwoju regionalnego lepszym scenariuszem byłoby utrzymanie stabilnego i proporcjonalnego wzrostu nakładów inwestycyjnych, powiązanego $\mathrm{z}$ sytuacją ekonomiczną w gospodarce realnej oraz z sytuacją dochodową budżetów jednostek samorządu terytorialnego.

\section{Rysunek 7. Wskaźnik tempa zmian wydatków majątkowych budżetów województw w 2013 r. (w \%)}

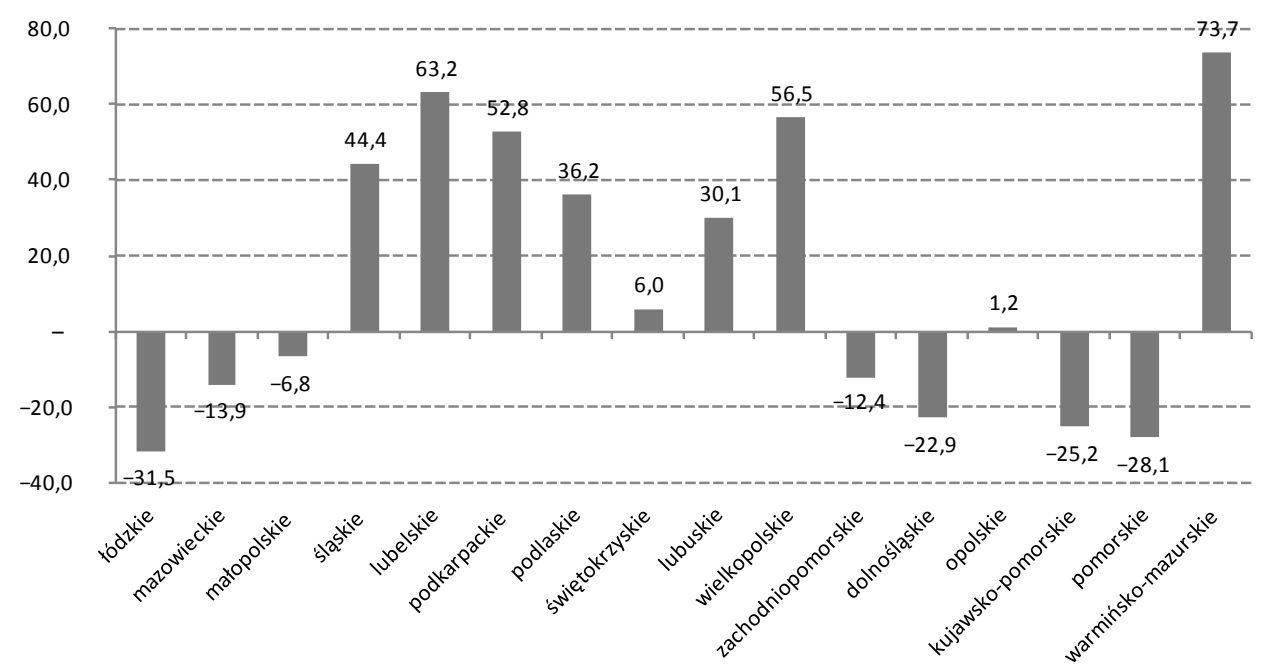

Źródło: Opracowanie własne.

Patrząc jednak na postępujące zmiany przez pryzmat zawirowań w systemie finansów, spowodowane światowym kryzysem finansowym, sytuacja w zakresie prowadzenia polityki inwestycyjnej oraz realizacji projektów inwestycyjnych $\mathrm{w}$ regionach w Polsce była w omawianym okresie złożona. Należy przypuszczać, że zdobyte doświadczenia, a także przewidywana poprawa ogólnej sytuacji gospodarczej sprawią, że w okresie programowania 2014-2020 wystąpią lepsze warunki do prowadzenia polityki inwestycyjnej jednostek samorządu terytorialnego oraz realizacji nowych projektów inwestycyjnych.

W tym miejscu należy także zwrócić uwagę na dane liczbowe charakteryzujące udział łącznych wydatków majątkowych jednostek samorządu terytorialnego wszystkich szczebli (gminy, powiaty, województwa) w wydatkach budżetowych jednostek samorządu terytorialnego ogółem w układzie regionów. Sytuację w tym zakresie przedstawiłem w tabeli 5 oraz na rysunku 8. 
Tabela 5. Udział wydatków majątkowych w wydatkach ogółem jednostek samorządu terytorialnego w latach 2008-2013 (w \%)

\begin{tabular}{|l|c|c|c|c|c|c|}
\hline \multicolumn{1}{|c|}{ Wyszczególnienie } & 2008 & 2009 & 2010 & 2011 & 2012 & 2013 \\
\hline Dolnośląskie & 23,1 & 26,6 & 23,5 & 22,4 & 20,1 & 17,9 \\
\hline Kujawsko-pomorskie & 20,4 & 23,0 & 22,9 & 22,6 & 20,3 & 17,8 \\
\hline Lubelskie & 19,2 & 20,5 & 23,8 & 24,5 & 19,6 & 20,7 \\
\hline Lubuskie & 16,6 & 30,4 & 27,1 & 19,5 & 12,7 & 13,6 \\
\hline Łódzkie & 22,0 & 27,7 & 23,9 & 19,7 & 17,7 & 18,1 \\
\hline Małopolskie & 21,4 & 25,5 & 24,1 & 24,3 & 18,7 & 16,7 \\
\hline Mazowieckie & 23,5 & 21,8 & 22,1 & 19,0 & 17,2 & 15,9 \\
\hline Opolskie & 18,1 & 24,5 & 23,8 & 20,5 & 14,8 & 14,5 \\
\hline Podkarpackie & 18,3 & 24,1 & 25,8 & 25,6 & 19,6 & 21,5 \\
\hline Podlaskie & 19,3 & 29,2 & 29,9 & 26,9 & 20,8 & 21,3 \\
\hline Pomorskie & 23,4 & 25,3 & 25,9 & 26,0 & 23,9 & 19,0 \\
\hline Śląskie & 22,0 & 24,4 & 23,5 & 21,4 & 18,6 & 20,4 \\
\hline Świętokrzyskie & 18,1 & 27,2 & 27,7 & 25,7 & 22,8 & 21,0 \\
\hline Warmińsko-mazurskie & 16,8 & 22,8 & 26,2 & 22,6 & 19,0 & 19,9 \\
\hline Wielkopolskie & 21,0 & 26,8 & 24,8 & 24,2 & 18,0 & 17,2 \\
\hline Zachodniopomorskie & 20,6 & 24,7 & 25,0 & 25,4 & 21,6 & 17,9 \\
\hline
\end{tabular}

Źródło: Opracowanie własne na podstawie danych GUS.

Rysunek 8. Udział wydatków majątkowych w wydatkach jednostek samorządu terytorialnego ogółem w 2013 r. (w \%)

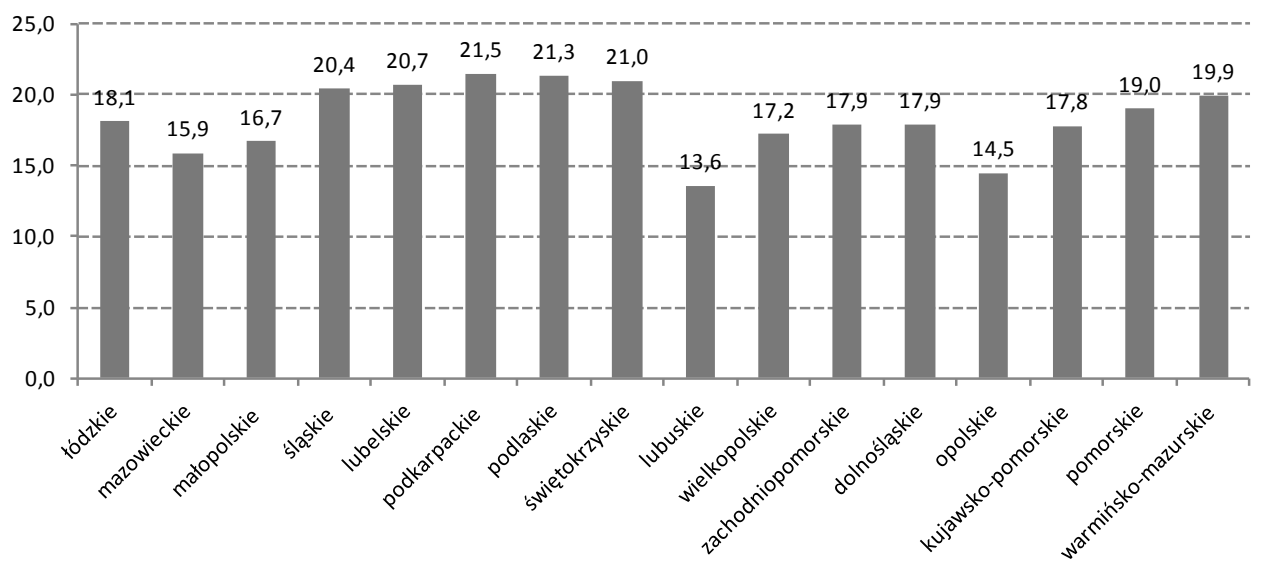

Źródło: Opracowanie własne na podstawie danych GUS.

Jak wynika z prezentowanych danych, sytuacja w zakresie udziału wydatków majątkowych w wydatkach ogółem jednostek samorządu terytorialnego (łączne 
wydatki jednostek samorządu terytorialnego szczebla lokalnego oraz regionalnego) w latach 2008-2013 była dość zróżnicowana. W okresie tym można było jednak zauważyć przejawy stagnacji w tym zakresie. Zasadniczo we wszystkich regionach udział wydatków majątkowych oscylował wokół wartości 20\%. W roku 2008 w dziewięciu regionach omawiany udział był wyższy od określonej umownie granicy, w pozostałych zaś był wyższy, nie przekraczając jednak granicy 24\%. W roku 2009 sytuacja uległa nieznacznej poprawie, mimo że był to czas najwyższych wydatków budżetowych w okresie objętym analizą. W dziewięciu regionach wskaźnik osiągnął wartości nieprzekraczające $25 \%$, w pozostałych był nieco wyższy. Jednak w kolejnych latach 2010-2013 nastąpił spadek udziału omawianej kategorii wydatków w wydatkach samorządu terytorialnego ogółem. W roku 2013 wartości wskaźnika przekroczyły $20 \%$ tylko w pięciu regionach, w pozostałych oscylowały w przedziale $15-20 \%$, natomiast w regionie lubuskim wartość wskaźnika uległa obniżeniu do poziomu 13,6\%.

Najwyższy udział omawianych wydatków w okresie 2008-2013 odnotowano w 2009 r., w niektórych regionach ukształtował się na poziomie powyżej 30\% lub był do tego poziomu zbliżony. W roku 2013 odnotowano niepokojąco niskie wartości wskaźnika w większości regionów. Jedynie w kilku regionach (świętokrzyski, podlaski, podkarpacki, lubelski i śląski) udział ten oscylował wokół $20 \%$. W pozostałych regionach uległ znacznemu obniżeniu, a w części z nich osiągnął poziom niższy niż w roku wyjściowym analizy (2008).

Sytuacja taka miała liczne uwarunkowania, o których już wspomniałem. Bez wątpienia było to związane z obniżeniem tempa wzrostu PKB zarówno w Polsce, jak i w krajach Unii Europejskiej, co nie było bez wpływu na budżetowe dochody własne regionalnych struktur samorządu terytorialnego, ze wzrostem kosztów obsługi zadłużenia, a także wahaniami transferów środków $\mathrm{w}$ ramach wsparcia $\mathrm{z}$ budżetu Unii Europejskiej. Uzyskiwane wyniki gospodarcze wyraźnie dowodzą, że mimo wielu korzystnych tendencji sytuacja budżetowa jednostek samorządu terytorialnego na poziomie regionów była niestabilna. Należy jednak zaznaczyć, że zjawisko to wystąpiło w warunkach wzrostu wolumenów wydatków inwestycyjnych, co w istocie oznaczało stopniowe zwiększanie nakładów majątkowych.

\section{Wnioski}

Badania empiryczne dotyczące inwestycji i polityki inwestycyjnej na poziomie regionów dowodzą, że zakres inwestycji realizowanych przez poszczególne regiony w Polsce kształtował się na zróżnicowanym poziomie. Mimo dość szybkiego wzrostu 
wolumenu wydatków już w pierwszych latach i dość wysokiego tempa zmian w $2010 \mathrm{r}$. odnotowano wyraźne osłabienie zarówno wolumenu wydatków inwestycyjnych, jak i tempa wzrostu.

Niezależnie od gorszych wyników gospodarki budżetowej na poziomie regionów należy stwierdzić, że w sferze inwestycji publicznych w ujęciu wartościowym i rzeczowym nastąpiła wyraźna poprawa. W stosunku do pierwszych lat transformacji społeczno-gospodarczej zakres przemian był duży i w zasadzie nie miał precedensu w historii gospodarczej ostatniego czterdziestolecia. W szczególności nastąpiły istotne zmiany o charakterze ilościowym i jakościowym, polegające na znaczącej poprawie jakości świadczonych usług.

Nie udało się uniknąć oddziaływania negatywnych czynników zarówno o charakterze endogenicznym, jak i egzogenicznym. Na niekorzystne zjawiska w sferze wydatków majątkowych i inwestycyjnych w wojewódzkich jednostkach samorządu terytorialnego wywarły wpływ przynajmniej trzy grupy czynników: ujawnione zjawiska kryzysowe na świecie oraz w Polsce, które nie pozostały bez wpływu również na przedsięwzięcia inwestycyjne podejmowane w sferze sektora publicznego w samorządzie terytorialnym szczebla regionalnego, w latach 2007-2013, a zwłaszcza od 2008 r. odnotowano wyraźny wzrost wydatków w regionach związanych z obsługą zadłużenia wygenerowanego w okresach wcześniejszych. Taka sytuacja musiała doprowadzić do ograniczenia zasobów, które w bezpieczny sposób mogłyby być kierowane na inwestycje. Ograniczenie to wystąpiło w sytuacji dość wyraźnego wsparcia projektów inwestycyjnych regionów ze strony budżetu Unii Europejskiej.

W części regionów nakłady inwestycyjne uległy zwielokrotnieniu, co w rezultacie doprowadziło do wyraźnych efektów rzeczowych w regionach. Nie ulega wątpliwości, że mimo sporych trudności z utrzymaniem stabilności finansowej w procesie finansowania zadań rozwojowych uzyskane efekty rzeczowe wyraźnie przyczyniły się do poprawy sytuacji w wielu zakresach, a zwłaszcza w sferze infrastruktury technicznej oraz społecznej w ramach społeczno-gospodarczej w układzie regionalnym, a także na poziomie lokalnym jednostek samorządu terytorialnego. W efekcie podjętych przedsięwzięć inwestycyjnych udało się wyraźnie zwiększyć potencjał rozwojowy regionów. Stanowią one aktualnie dobry punkt wyjścia do podejmowania nowych projektów inwestycyjnych, które będą mogły być skutecznie finansowane w kolejnym okresie programowania budżetowego Unii Europejskiej przy wsparciu unijnych środków budżetowych. 


\section{Regional public investments in Poland between 2008-2013}

The main objective of the Polish investment policy during transition and accession to the European Union was to increase investment in both the private and the public sector. The investment policy at that time had to be conducted on the basis of far-reaching autonomy of public sector units. The article concentrates on the economic analysis and evaluation of the effects of regional investment policy, focusing on the expenditures between 2008-2013.

Keywords: public sector, investment policy, public finance

\section{Les investissements publics au niveau régional en Pologne entre 2008 et 2013}

L'objectif principal de la politique d'investissement polonaise lors de la transformation et l'adhésion à l'Union européenne était d'accroître les investissements dans le secteur privé et le secteur public. La politique d'investissement à l'époque a dû prendre en compte l'autonomie des unités du secteur public. L'article traite de l'analyse économique et de l'évaluation des effets de la politique d'investissement au niveau régional en Pologne, en mettant l'accent sur les dépenses entre 2008 et 2013.

Mots-clés: le secteur public, la politique d'investissement, les finances publiques

\section{Региональные общественные инвестиции в Польше в 2008-2013 гг.}

Основной задачей инвестиционной политики в переходный период и после вступления Польши в Европейский союз была необходимость увеличить инвестиции в частном и государственном секторах. Инвестиционная политика тогда должна была учитывать далеко идущую автономию субъектов государственного сектора. Статья включает анализ и оценку результатов общественных инвестиций в регионах, а внимание было сосредоточено на капитальных расходах в 2008-2013 гг.

Ключевые слова: государственный сектор, инвестиционная политика, публичные финансы 
